\title{
Cousin Marriage in the Light of Islam and Medical Science
}

\author{
Dr. Muhammad Zahid \\ Associate Professor, Islamic Studies, Khyber Medical College, Peshawar, Pakistan \\ Email: zahid umar1966@yahoo.com \\ Dr. Ashfaq Ali \\ Lecturer, Department of Islamic Theology, Islamia College, University, \\ Peshawar, Pakistan \\ Email: ashfaqali@icup@edu.pk
}

\begin{abstract}
:
Cousin marriage is considered to be a cause of viral diseases in the societies where it is in practice. This study focuses on the practice of cousin marriage in the light of Islam and medical science. Various holy texts regarding Maharim, non-Maharim and marriage were studied in detail. Analyses of the studies about diseases that are counted with consanguineous marriages were carried out. It was observed that there were a number of rare disorders described in medical science linked with cousin marriages. Islam, taking into account this drawback in cousin marriage encourages marriages outside the family, so that the social circle is widened and deadly diseases in health can be avoided.
\end{abstract}

Keywords: Congenital Disorders, Cousin Marriage, Medical, Islam

\section{Introduction:}

Marriage is a divine favour that God bestows on His servants. A series of verses from the holy Qur'an indicate this fact as God says:

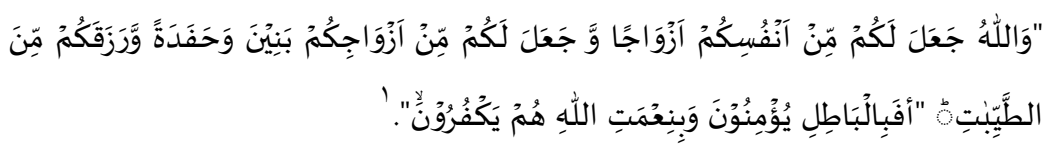

And Allah has given you spouses from your kind, and has granted you through your spouses, sons and grandsons, wholesome things as sustenance. (After knowing all this), do they still believe in falsehood and deny Allah's bounty.

Thus Islam has encouraged the beautiful bond of Nikah or marriage and considers it a very essential step toward a stable life in the society. Opinions and practice vary widely across the world. In some cultures and communities, cousin 
marriage is considered ideal and actively encouraged; in others, it is subject to social stigma.

Islam does not discourage marriage among cousins. But Imam Shafi and Imam Ahmad, the two leading scholars of the Sunni school of thought dislike cousin marriage and have declared it as makruh. Similarly, some other scholars like Imam Ghazali have also discouraged cousin marriage.

In medical science cousin marriages are considered major risk factors for Bipolar disorders. This marriage system has been reported as an important factor in the appearance of autosomal recessive diseases and congenital anomalies, including hydrocephalus, postaxial hand polydactyl and bilateral cleft lip cleft palate, bipolar disorders, depression, reproductive disorders, sterility, infant mortality, child deaths, spontaneous abortions and stillbirths etc. Also there are reports indicating positive association between consanguinity and Down syndrome, and also ventricular septal defect (VSD), atrial septal defect (ASD), atrioventricular septal defect (AVSD), pulmonary stenosis (PS) and pulmonary atresia (PA). The risk for birth defects in the offspring of first cousin matings has been increased to $5-8 \%$ compared to $2-3 \%$ in marriages taking place outside the family ${ }^{2}$

\section{Discussion}

The Qur'an does not state that marriages between first cousins are forbidden. In Sura An-Nisa Allah Says:

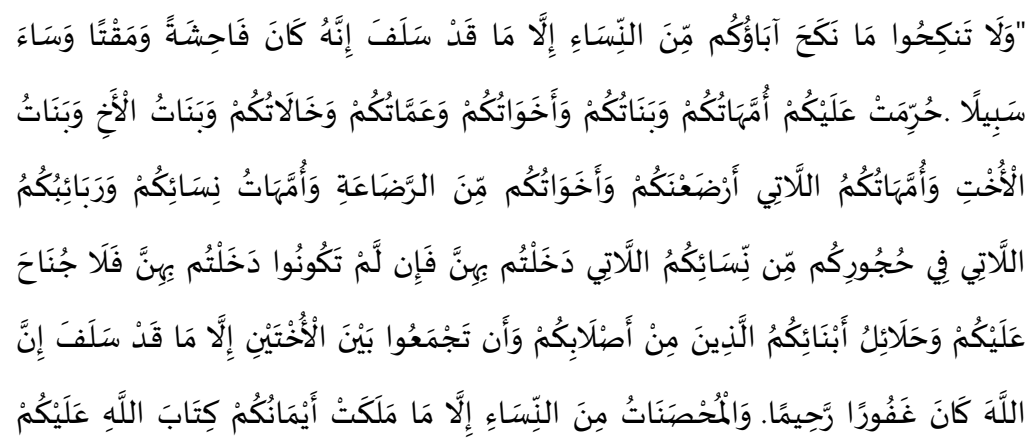




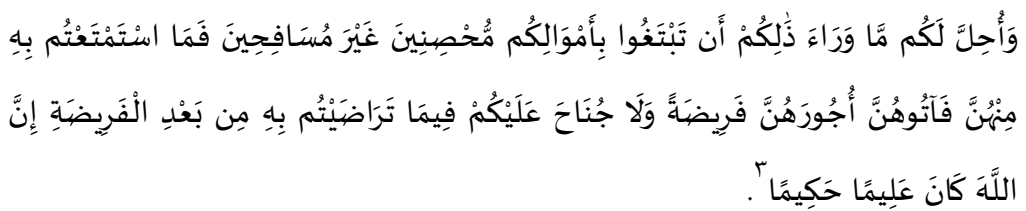

And do not marry those [women] whom your fathers married, except what has already occurred. Indeed, it was an immorality and hateful [to Allah] and was evil in a way. Prohibited to you [for marriage] are your mothers, your daughters, your sisters, your father's sisters, your mother's sisters, your brother's daughters, your sister's daughters, your [milk] mothers who nursed you, your sisters through nursing, your wives' mothers, and your step-daughters under your guardianship [born] of your wives unto whom you have gone in. But if you have not gone in unto them, there is no sin upon you. And [also prohibited are] the wives of your sons who are from your [own] loins, and that you take [in marriage] two sisters simultaneously, except for what has already occurred. Indeed, Allah is ever forgiving and Merciful.And [also prohibited to you are all] married women except those your right hands possess. [This is] the decree of Allah upon you. And lawful to you are [all others] beyond these, [provided] that you seek them [in marriage] with [gifts from] your property, desiring chastity, not unlawful sexual intercourse, so for whatever you enjoy [of marriage] from them, give them their due compensation as an obligation, and there is no blame upon you for what you mutually agree to beyond the obligation. Indeed, Allah is ever knowing and Wise.

Allah mentioned the women who are forbidden for marriage: to quote the Qu'ran, "Lawful to you are all beyond those mentioned, so that you may seek them with your wealth in honest wedlock. ${ }^{4}$ In Sura Al-Ahzab God says: 


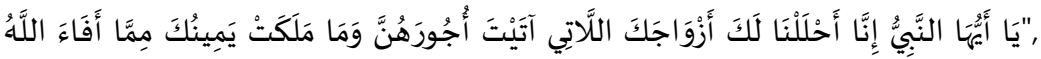

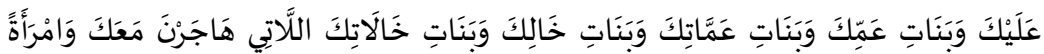

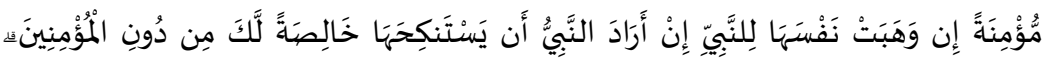

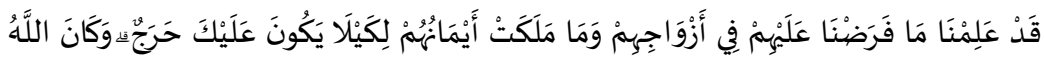

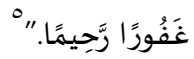

O Prophet, indeed We have made lawful to you your wives to whom you have given their due compensation and those your right hand possesses from what Allah has returned to you [of captives] and the daughters of your paternal uncles and the daughters of your paternal aunts and the daughters of your maternal uncles and the daughters of your maternal aunts who emigrated with you and a believing woman if she gives herself to the Prophet [and] if the Prophet wishes to marry her, [this is] only for you, excluding the [other] believers. We certainly know what we have made obligatory upon them concerning their wives and those their right hands possess, [but this is for you] in order that there will be upon you no discomfort. And ever is Allah Forgiving and Merciful.

Muslims have practiced marriages between first cousins in non-believing countries since the time of Muhammad. In a few countries the most common type is between paternal cousins. ${ }^{6}$

Muhammad actually did marry two relatives.(9)One was a first cousin, Zaynab bint Jahsh, who was not only the daughter of one of his father's sisters but was also divorced from a marriage with Muhammad's adopted son, Zayd ibn Haritha. It was the issue of adoption and not cousinship that caused controversy due to the opposition of pre-Islamic Arab norms ${ }^{7}$

Many of the immediate successors of Muhammad also took a cousin as one of their wives. Umar married his cousin Atikah bint Zayd ibn Amr ibn Nifayl, ${ }^{8}$ 
while Ali married Fatimah, ${ }^{9}$ the daughter of his paternal first cousin Muhammad $(\mathrm{SAW}) .{ }^{10}$

The risk of having a baby with birth defects - usually heart or nervous system problems which can sometimes be fatal - is still small, but it rises from $3 \%$ in the general Pakistani population to $6 \%$ among those married to blood relatives. The researchers also found a doubling of the risk in the babies of white British women who were over the age of 34 . It has already been established that the risk increased from 2 to 4 percent. Every year there are about 90 more baby deaths than would be expected in the Pakistani community because of birth defects. The issue is highly sensitive as marriages within families are happening on regular basis without looking into the consequences. It is a very known fact that genes are passed down from person to person and everyone in a family shares some percentage of their genes with everyone else in their family. This is why we are linked to everybody in our family tree.

Some members of a family are more closely related than others because we share more of our genes with our brothers and sisters than we do with our uncles or aunts. That's why we usually (but not always) look more like our brothers or sisters or parents than other people in our families.

Brothers and sisters are very closely related to one another as they share about $50 \%$ of their genes. The same is true for parents and children. First and second cousins share fewer genes. First cousins only share about $12.5 \%$ of their genes and second cousins only $3.1 \%$.

No matter how different members of the same family tree appear, they definitely share some genes in common, which means they are also more likely to share any type of gene versions that may cause series disabilities.

So there is the possibility of having children with critical health conditions in close family marriages and they are more likely to share the same 
"problem" genes and so more likely to pass them down to their children. In the case of cousins this risk is higher than the risk of strangers having a child with a disability. Normally people have a 2 to 3 percent chance of having childern with disabilities.

First cousins only have a risk of $4-6 \%$ of having a child with a disability. This means that $94-96 \%$ of the children are healthy and have no issues. The risk for second cousins to have a child with a disability is even lower. Their risk is just a bit higher than the $3 \%$ risk that all unrelated couples have. So, for every 100 second cousins who have kids, 96-97 children are perfectly healthy.

The bottom line is that there is a greater risk of disability for a child be born to a couple who are either first or second cousins. ${ }^{11}$

Holy Prophet (saw) said, "Don't marry a near relative (such as a first cousin) as it results in a defective or weak child that is born" ${ }^{12}$

However, leading researcher in genetics believe that Marriages between first cousins, has long been a legal, social and religious taboo, is far less likely to cause abnormalities in children than is commonly assumed. ${ }^{13}$ The study says: "Stigma still attaches to the union"14

"But there's no good social or biological reason that should be. There's a lot of misinformation out there that is really holding back some cousins who want to try to have children.

Bennett's team, which included researchers from Stanford University and the National Society of Genetic Counselors, spent more than two years studying health statistics on the offspring of first-cousin marriages in North America, Africa, Asia and the Middle East.

The researchers concluded that children of marriages between cousins inherited recessive genetic disorders, such as cystic fibrosis and Tay-Sachs disease, in $7 \%$ to $8 \%$ of cases. For the general population, the rate was $5 \%$. 
The study suggests that doctors and genetics counselors not discourage cousins from procreating. Instead, it says, they should take family disease histories and offer ordinary genetic services such as fetal and newborn disease testing. Despite the findings, some genetics specialists say they will continue to urge caution.

"A 7 to $8 \%$ chance (of genetic disorder) is $50 \%$ greater than a $5 \%$ chance," 15

"That's a significant difference. People counseling first cousins who want to marry need to be very careful and clear on this," Reilly says.

Scientists say there are at least 5,000 diseases caused by inherited mutations called recessive genes. Possessing a single copy of the mutation is often harmless, but if a copy is inherited from each parent, the result can be death or chronic disease because first cousins share a pair of gens from grandparents and the chances are greater that each will pass a copy of a "bad gene" to their child, triggering the disorder.

There is no restrictions on cousin marriages in Islam, but we see that marriage between cousins is not recommended in some hadiths due to some hereditary and medical drawbacks.

While listing the qualities to be sought in spouses to marry in accordance with the sunnah, Imam Ghazali states that one should not marry his cousin. He quotes the following hadith: "Do not marry a woman who is a close relative of yours because your child will be weak and puny. "16

When this drawback is taken into consideration, marrying a close relative is not recommended. The following hadith attracts attention to that issue: "Marry people who are not your relatives; do not marry your close relatives "17 
Another important disadvantage about marrying a close relative is this; when there is a conflict between the spouses, the relationship begins to deteriorates among which otherwise needs to be maintained at any cost.

It will be very useful to check blood incompatibility before marriage especially before marriage with a close relative as a medical precaution.

As we have mentioned before, there is nothing prohibiting marriage with close relatives in Islam in principle. The medical risks that are mentioned are not certain. However, disabilities and similar diseases are observed more in marriages between close relatives in comparison to marriages between people who are not relatives.

\section{Conclusion:}

Islam has not discouraged marriage within a family among first or second cousins, it only encourages marriage outside the family. The following factors must be considered to see the benefits of marriage outside family:

1. It will lead to strengthen the bond and will increase the social circle of a person. Marrying a person outside ones family will make that person know more and more individuals around him. He will get along with people from a completely different area and that will be a beautiful addition to his family.

2. Even the marital bonds are not always perfect. Separation can occur in the form of divorce between a husband and wife, so if a person marries someone from his family then divorcing her will break that strong family bond as well and in this way long disputes among close family members is created.

3. Medical science has proved the disadvantages of cousin marriages in the form of various medical disorders and various rare diseases and syndromes. Thus before cousin marriages blood compatibility and genetic testing must be carried out as a precaution. 
Keeping in view the above mentioned facts it is good to marry outside family. In conclusion, it is clear that Islam, undoubtedly, permits cousin marriages. As for the issue of preference in choosing a life partner from outside one's family, this varies from person to person depending on their positions. Yet, Islam is generally keen on widening the circle of social bonds in order to overcome the fear of hereditary diseases, it is a good practice to have a blood test before marriage. If one suspects some hereditary disease or any other problem then he/she should seek the advice of a medical expert in this field.

\section{References \& Notes:}

1. Al-Quran 16:72

2. Risk factors of various diseases in cousin marriages from Medical encyclopedia, Retrieved: 10-4-20018

3 . Sura An-Nisa (4:22-24)

4. Al-Quran 33:50

5. Al-Ahzab,

6. Chapter (33) sūrat 1-aḥzāb (The Combined Forces)". corpus.quran.com. Retrieved: 25-02-2019

7. Author Watt,Book : Muhammad at Medina, P. 330

8. "History of the Prophets and Kings " vol 4 page :199 by Muhammad ibn Jarir al-Tabari" al-Bidayah wa al-Nihayah "chap 6 page 352 by ibn Kathir

9 $\quad$ Fatimah bint Muhammad. MSA West Compendium of Muslim Texts."Fatimah", Encyclopedia of Islam. Brill Online. Retrieved 17-02-2019

10. Nasr, Seyyed Hossein. "Ali". Encyclopedia Britannica Online. Encyclopedia Britannica, Inc. Retrieved 14-01-2018

11. Al-Ani ZR1. Department of Pediatrics, Medical College, Al-Anbar University, Al-Ramadi, Iraq. 1995

12. Quoted by Imam Ghazali in 'Ihya Ulum id Din', Vol. 5, pp 190-191

13. The study is in the April 2016 edition of the Journal of Genetic Counseling.

14. Nasr, Seyyed Hossein. "Ali". Encyclopedia Britannica Online. Encyclopedia Britannica, Inc. Retrieved 14-01-2019

15. Philip Reilly, geneticist and author of Abraham Lincoln's DNA, a popular history of human genetics, p. 17, Syracuase Press, 2009

16. Tarbiyatu'l-Awlad, 1: 39; Ihya Ulloom al Din, 2: 42.

17. Qadi Baydawi. Gâyetü'l-Gusâ, 2: 721. 


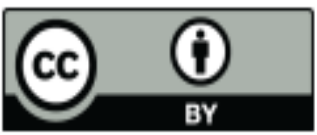

@ 2017 by the author, Licensee University of Chitral, Journal of Religious Studies. This article is an open access article distributed under the terms and conditions of the Creative Commons Attribution (CC BY) (http://creativecommons.org/licenses/by/4.0/). 